\title{
On the World Economic Elite
}

\author{
Adolfo Figueroa* \\ José María Rentería ${ }^{* *}$
}

\begin{abstract}
Economic elites have not received enough attention in the economic literature. The obvious reason is limited access to information. This paper seeks to contribute to contemporary knowledge on elites in two ways. First, it employs a new unique data set on the world economic elite covering 2002-2014 to develop a method of measuring the degree of elite circulation; second, it provides a theoretical explanation of the observed facts. The empirical finding is that the world economic elite is subject to a low degree of circulation. Despite increased globalization, liberalization, longterm economic growth, and the recent Great Recession, the core of the elite remains mostly unchanged. Our theory attempts to explain this fact by introducing the analytical distinction between market competition and elite competition, which is a kind of meta-competition. Thus, the following relationship is derived from the theory: The low level of elite circulation, that is, the low meta-competition, underlies the oligopolistic market structures that we observe in the real world.
\end{abstract}

Key words: Economic elites, elite competition, wealth concentration.

JEL Classification: D31, D40, O24.

\section{Acerca de la élite económica del mundo}

\section{RESUMEN}

Las élites económicas no han recibido suficiente atención en la literatura económica. La razón evidente es el acceso limitado a información. Este estudio busca contribuir al conocimiento contemporáneo sobre elites de dos maneras. En primer lugar, utilizando una nueva base de datos de las élites económicas mundiales que cubre el periodo 2002-2014, se desarrolla un método para medir el grado de circulación de las élites; en segundo lugar, se ofrece una explicación teórica de los hechos observados. El hallazgo empírico consiste en que la élite económica mundial muestra un bajo grado de circulación. A pesar de la mayor globalización, liberalización, crecimiento económico de largo plazo y una gran recesión económica reciente, el núcleo de las élites permanece casi inmutable. Nuestra teoría explica este hecho introduciendo la distinción analítica entre competencia de mercado y competencia de la élite, la cual es una especie de metacompetencia. Luego,

* CENTRUM Graduate Business School, Pontificia Universidad Católica del Perú.

** Department of Economics, Pontificia Universidad Católica del Perú and Instituto de Estudios Peruanos. Correspondence to: jmrenteria@pucp.pe.

The authors would like to thank José S. Rodríguez and the two anonymous referees for their valuable comments on the first draft. 
la siguiente relación es derivada de la teoría: el bajo nivel de circulación de las élites, es decir, la baja meta-competencia, subyace a las estructuras oligopolísticas de mercado que se observan en el mundo real.

Palabras clave: élites económicas, competencia de la élite, concentración de la riqueza.

Clasificación J.E.L.: D31, D40, O24.

\section{INTRODUCTION}

Economic analysis of the economic elite is not common. Compared to the thousands of studies about poverty, the elite has received less attention in the literature. The obvious reason for this is lack of information. Whereas researchers and interviewers can easily visit poor households and ask them the questions they want through direct contact, studying the economic elite through this method is not viable. In a sense, researchers tackling this area are reduced to the astronomer's problem of attempting to study their subject - wealthy households - at a distance, only without the help of a telescope.

The only sources available to study the economic elite come from private firms that have access to information on the financial management of the very wealthy and are able to disclose some of this information, such as Forbes and Credit Suisse. Rankings of the very wealthy stand as the most common source of information; however, these sources do not reveal their calculation methods, so there are questions as to exactly how reliable such information might be. Nonetheless, this is all that we researchers have access to.

Recently, Oxfam published a data set on the net worth of the world's wealthiest people for the period 2002-2014 based on the annual Forbes' billionaires list (Oxfam, 2015). ${ }^{1}$ This new data set is very valuable given its relatively long period of observation whereby the method of calculation (whatever it may be) is expected to be uniform, making the data set comparable. Moreover, that the list refers to the 80 richest people in the world for each year places it as a unique data set with which to learn something about the world's economic elite.

Elites are defined as those social groups at the top of any rankable social-power scale (Bodley, 1999). Hence, the economic elite can be seen as the social group at the top of the rankable wealth scale. The study of elites is important because of the economic power concentrated in their hands. Economic and political elites constitute the fundamental power structure of capitalism. But paradoxically given the power they wield, and as noted above, our knowledge about world economic elites is still incipient.

1 This study was presented two days before the World Economic Forum of 2015, a meeting to which Oxfam International's Executive Director Winnie Byanyima was invited as a co-chair. 
This paper seeks to contribute to the literature in three ways. First, it analyzes the new data set collected by Oxfam on the world economic elite; second, it develops a method to measure the mobility within the elite (the index of elite circulation); and third, it provides a theoretical explanation of the observed facts.

\section{THE FACTS}

Table 1 shows the annual aggregate data on net worth of the individuals comprising the world economic elite for the period 2002-2014. The value of net worth is measured in nominal dollars of each year. Trends in real values are unavailable. However, the fall in total and mean values in 2009 and 2010, in nominal values, indicates that the global financial crisis had a significant effect upon the net worth of the world's economic elite, which took around four years to recover. By comparison, we estimate that the 80 wealthiest people in 2014 had a total wealth equivalent to $12 \%$ of the US GDP of the same year, as reported by the World Bank (2014, p. 297).

As regards the dispersion of the mean value within the group of 80 people, measured by the Pearson coefficient of variability, we can see that it tends to decrease over time. The differences in the extreme values also tend to diminish. The data set shows that in 2014 the richest billionaire possessed US \$76 billion dollars, whereas the least wealthy had US $\$ 13$ billion, a sixfold difference; in the first years of the period, the gap was around tenfold. Thus, the distribution of net worth among the elites of 2013-14 tends to be more homogeneous compared to the list of 2002-03.

Table 1. Net worth of the 80 richest people in the world, 2002-2014 (\$ mil)

\begin{tabular}{rrrrrrc}
\hline Year & \multicolumn{1}{c}{ Total } & \multicolumn{1}{c}{ Mean } & Std. Dev. & CV & \multicolumn{1}{c}{ Min. } & Max. \\
\hline 2002 & 772000 & 9650 & 7951 & $82 \%$ & 4300 & 52800 \\
2003 & 701600 & 8770 & 6198 & $71 \%$ & 4000 & 40700 \\
2004 & 871400 & 10893 & 7263 & $67 \%$ & 5200 & 46600 \\
2005 & 936600 & 11708 & 7341 & $63 \%$ & 5600 & 46500 \\
2006 & 1022900 & 12786 & 7251 & $57 \%$ & 6700 & 50000 \\
2007 & 1270000 & 15875 & 8875 & $56 \%$ & 8500 & 56000 \\
2008 & 1532900 & 19161 & 10801 & $56 \%$ & 10000 & 62000 \\
2009 & 942000 & 11775 & 6631 & $56 \%$ & 6000 & 40000 \\
2010 & 1289000 & 16113 & 8798 & $55 \%$ & 8500 & 53500 \\
2011 & 1512700 & 18909 & 10499 & $56 \%$ & 10100 & 74000 \\
2012 & 1516200 & 18953 & 10029 & $53 \%$ & 10900 & 69000 \\
2013 & 1659700 & 20746 & 11517 & $56 \%$ & 12000 & 73000 \\
2014 & 1898600 & 23733 & 12901 & $54 \%$ & 13400 & 76000 \\
\hline
\end{tabular}

Note: Current FX, money of the day.

Source: Oxfam (2015). Compiled by authors. 
Table 2 shows the rotation, or circulation, of the 80 individuals on the list over time. The total number of people to have appeared on the Forbes list over the 13-year period covered is 193 . According to this table, 21 people appeared on the list every year - that is, 13 times, whereas 40 people appeared only once; the former group of 21 people could be considered the hardcore of the world economic elite because they also constitute the wealthiest group, as will be shown below.

Table 2. Number of years in which individuals appear among the 80 richest people in 2002-2014

\begin{tabular}{ccc}
\hline Number of years & Freq. & \% ofthe total list ${ }^{1 /}$ \\
\hline 13 & 21 & $11 \%$ \\
12 & 8 & $4 \%$ \\
11 & 6 & $3 \%$ \\
10 & 7 & $4 \%$ \\
9 & 10 & $5 \%$ \\
8 & 3 & $2 \%$ \\
7 & 9 & $5 \%$ \\
6 & 12 & $6 \%$ \\
5 & 12 & $6 \%$ \\
4 & 16 & $8 \%$ \\
3 & 24 & $12 \%$ \\
2 & 25 & $13 \%$ \\
1 & 40 & $21 \%$ \\
\hline
\end{tabular}

1/ There are 193 different names among the 80 richest people between 2002 and 2014. Thus, this column is calculated by dividing Freq./193.

Source: Oxfam (2015). Own elaboration.

Table 3, Column 1, shows that the hardcore represents $26 \%$ of the people in the group of $80(21 / 80)$, in which an average of $38 \%$ of the group's total net worth is concentrated. This percentage varies between $33 \%$ and $44 \%$, depending on the year. It should be noted that the average share of $38 \%$ does not change in 2009 , the year in which the economic crisis unfolded. Column 2 shows that the mean net worth of the core was $75 \%$ higher on average than that of the rest over the period. Thus, the hardcore of the elite is also the richest group. Finally, Column 3 sets out the Gini coefficient for each year, with an average value of 0.27 . The range goes from 0.23 to 0.36 . The first years of the period can be seen to have higher Gini values, but they remained almost stable over the last nine years.

The average value of the Gini coefficient (0.27) is much smaller than what some studies have reported in relation to the concentration of wealth at national level in the First World. For example, the Gini value for the United States in 1995 was 0.83 (Wolff, 1998, table 12), and was 0.67 , on average, for a sample of 19 countries in 2000 
(Davies et al., 2010, p. 246). Piketty's study (2014, table 7.2) presents estimates of Gini coefficients for 2010 in Europe and the USA, which have values of 0.67 and 0.73 , respectively. Therefore, the world economic elite is a much more homogenous social group in relative terms. On statistical grounds, this result should not be surprising, in that the elite group is a sample drawn from the upper tail of the national wealth distributions; however, what is surprising is the magnitude of the differences in wealth concentration.

Table 3. Wealth concentration among the 80 richest people in the world, 2002-2014

\begin{tabular}{cccc}
\hline & Core share $^{1 /}$ & Core relative mean $^{2 /}$ & Gini coefficient $^{3 /}$ \\
\hline Mean & 0.38 & 1.75 & 0.272 \\
2002 & 0.44 & 2.17 & 0.361 \\
2003 & 0.40 & 1.87 & 0.320 \\
2004 & 0.40 & 1.90 & 0.299 \\
2005 & 0.40 & 1.88 & 0.289 \\
2006 & 0.38 & 1.73 & 0.258 \\
2007 & 0.37 & 1.65 & 0.249 \\
2008 & 0.33 & 1.40 & 0.259 \\
2009 & 0.38 & 1.73 & 0.267 \\
2010 & 0.37 & 1.66 & 0.253 \\
2011 & 0.37 & 1.64 & 0.249 \\
2012 & 0.37 & 1.68 & 0.233 \\
2013 & 0.38 & 1.73 & 0.242 \\
2014 & 0.38 & 1.73 & 0.254 \\
\hline
\end{tabular}

${ }^{1 /}$ Share of the core in total net worth of the group of 80 .

${ }^{2 /}$ Average net worth of the core relative to that of the rest.

${ }^{3 /}$ Gini coefficient, where $\mathrm{n}=80$.

Source: Oxfam (2015). Own elaboration.

Table 4 shows the origin of the elite group. Among the hardcore, the vast majority 18 out of 21 individuals - are nationals of First World countries. As to the rest, the table shows that 58\% are from First World countries, 26\% from the Third World, and 16\% from non-capitalist countries (see country classification in the Appendix, Table A1.1). ${ }^{2}$ Overall, people from the First World predominate in the world economic elite.

2 Classification is based on income per capita levels in the period 1950-2010 and the dominant political regimes in that period; cf. Figueroa (2015, volume 1, chapter 2). 
Table 4. Elite groups by country type, 2002-2014

\begin{tabular}{|c|c|c|c|c|c|c|}
\hline \multirow{2}{*}{ Total } & \multicolumn{2}{|c|}{ Total } & \multicolumn{2}{|c|}{ Core group } & \multicolumn{2}{|c|}{ Rest } \\
\hline & 193 & $100 \%$ & 21 & $100 \%$ & 172 & $100 \%$ \\
\hline First World & 118 & $61 \%$ & 18 & $86 \%$ & 100 & $58 \%$ \\
\hline Third World & 48 & $25 \%$ & 3 & $14 \%$ & 45 & $26 \%$ \\
\hline Non capitalist & 27 & $14 \%$ & 0 & $0 \%$ & 27 & $16 \%$ \\
\hline
\end{tabular}

Note: Country classificatión is detailed in table A1.1

Source: Oxfam (2015). Own elaboration.

\section{MEASURING CIRCULATION OF THE ELITE}

The question known as the "circulation of the elite" refers to changes in the membership of the elite. If membership changes continuously, then there can be said to be a high degree of elite circulation in society. Conversely, if membership remains almost unchanged, the degree of elite circulation is low.

Economic elites are important in understanding society because they have power and because their degree of circulation shows the degree of economic mobility in society. Therefore, the problem of circulation of the elite concerns the changes in the social composition of these groups. Differences in composition would imply different forms and degrees of economic power in society.

We will now turn our attention to determining how much circulation has taken place in the world economic elite in the past 13 years. The data set presented above can help us answer this question. ${ }^{3}$

We propose an index capable of measuring the degree of elite circulation, as no such index can be found in the literature. Intuitively, the simplest way to measure the degree of circulation would be by comparing the extreme cases; if no name were repeated on the elite list, then the total number of members of the 80 -strong group of elites over the period would be 1040 individuals - that is, 13 times 80 . This would be a case of perfect circulation or a degree of circulation equal to one. On the other extreme, if the same names were repeated year after year, then the list would be made up of 80 people. This would be a case of zero circulation.

The data set contains 193 people listed across the 13-year period. Thus, a first index of circulation could be $193 / 1040=0.186$. This index indicates low circulation. However, this index ignores the frequency distribution of names. The 193 names may have different distributions. The observed data is shown in Table 2. We can deduct from 193 the 21 names that are repeated every year, which we have defined as the hardcore of the elite. Hence, we are left with 172 people who have truly circulated (in and out).

3 The complete data set is reported in Appendix A3. It also can be downloaded from Oxfam's website: http://policy-practice.oxfam.org.uk/publications/wealth-having-it-all-and-wanting-more-338125 
Therefore, the second index would be equal to $172 / 1040=0.165$. If we consider a third index in which the core is defined as the people who appear all the time or most of the time on the list (seven or more years out of 13), which amounts to 64 people, we get an index of $129 / 1040=0.124$.

Using the latter definition for the core of the elite, we propose the following index of elite circulation $(C)$ :

$$
C=\frac{N-n}{E T}
$$

In this index, the symbol $E$ represents the size of the elite that is defined in the study, $T$ the number of years under observation, $N$ the total number of people who appear in the list in period $T$, and $n$ the number of people that appear on the list all the time or most of the time (the nucleus or core), such that the following inequalities hold true: $N \geq n, N \leq E T$ and $n \leq E$. According to the index $C$, the higher the value of $C$, the higher the degree of circulation; thus, it is indeed an index of circulation. Moreover, the higher the number of people whose names are repeated, the lower the value of $C$, and thus the lower the degree of circulation. At one extreme, if the list included the same names, repeated year after year, then $N=n=E$ and $C=0$. At the other extreme, if no name were ever repeated, then $N=E T$ and $n=0$, which implies $C=1$. For a given value of $E$, the index $C$ will be able to measure changes in the circulation of elites over time.

The index of circulation of the world economic elite is, according to our data set, equal to $0.124(E=80, T=13, N=193, n=64)$. The conclusion is that the degree of circulation in the period 2002-2014 was too low - that is, far from perfect circulation and much closer to lack of circulation. In this period of extensive globalization and liberalism, there is not much mobility in the elite group. More specifically, 64 people constitute the core of the world economic elite.

It is clear that index $C$ takes into account only a point of the frequency distribution of names, not the entire distribution. This may be called the simple elite circulation index. We also present the circulation index $C^{*}$, which takes into account the entire distribution; thus, it may be called the integral elite circulation index. The $C^{*}$ index has three components: $c$, the basic circulation (empirical list in relation to the theoretical maximum); $p_{1}$, a penalty for mortality rate; and $p_{2}$, a penalty for frequency distribution, such that both penalties must satisfy: $p_{1} \in[0,1]$ and $p_{2} \in[0,1]$.

$$
C^{*}=c \cdot p_{1} \cdot p_{2}
$$

Where,

$$
\begin{gathered}
c=\frac{N}{E T}=C+\frac{n}{E T} \\
p_{1}=1-\frac{m}{N} \\
p_{2}=\ln \left(e^{1-J}\right)
\end{gathered}
$$


Here $m$ is the number of deaths in the elite during the period $T . J$ captures the frequency distribution function through a weighted average, where the weights are the square of the number of times that each name appears. ${ }^{4}$ Note that the two indexes are positively related - that is, the simple index is contained in the integral index. According to our data set, $c=0.186$ and $p_{2}=0.728$. Assuming that no member of the elite dies between 2002 and 2014 (which is an optimistic assumption), then $p_{1}=1$. Therefore, the integral circulation index is $C^{*}=(0.186)(1)(0.728)=0.135$.

Compared to the simple circulation index (0.124), this estimate shows slightly higher elite circulation, but it remains low-level. Therefore, both estimates point to the same observed fact: there is a low degree of circulation among the world economic elite.

\section{AN EXPLANATORY THEORY AND SOME HYPOTHESES}

Why do we observe a low degree of elite circulation? In the period 2002-2014, many changes took place in the world economy, including the Great Economic Depression. Yet the core of the economic elite has remained almost unchanged. The circulation of the world economic elite seems, from our empirical results, not to be endogenous in the economic process. The Great Depression had a quantitative effect upon the average value of the net worth of the elite, as shown in Table 1 . However, it had no significant qualitative effect on the circulation of the elite. The long process of globalization continued during this period, and yet circulation remained unchanged.

A theory of economic elites, where its members are capitalists who own large amounts of physical and financial capital, has been proposed by Figueroa (2008). This theory can be summarized as follows:

Members of economic elites seek to maximize economic returns and at the same time to maintain their privileged position in society; between these two objectives, elites have lexicographic preferences: Social position has priority. Elites are not willing to substitute social position in exchange for higher economic returns.

Certainly, it is not just a matter of desire to maintain privileged position. For this to happen, elites must avail themselves of mechanisms that lead to such an objective, thus avoiding the risk of being "dethroned". As such, utilization of the advantages of being wealthy serves as this mechanism. The theory predicts the behavior of the elite as follows:

(a) Economic elites will invest in a portfolio of projects that has high mean returns even if it is subject to high risk, because of the large capacity of this group to bear heavy losses.

(b) Financing is not a limitative factor for investing in projects because, in addition to their own profits, elites have easy access to capital markets.

\footnotetext{
4 More details about the $C^{*}$ index specification are given in Appendix A2.
} 
(c) Because elites operate in international markets, their influence on national governments is great, as they can threaten governments with the reallocation of their investment to other countries; thus, they are able to negotiate domestic investment with governments on very favorable terms.

(d) They are able to invest in $\mathrm{R} \& \mathrm{D}$ to increase economic returns on their investments.

(e) They are able to gain membership of social networks that are entirely restricted to the wealthy. Inheritance is another mechanism.

The basic mechanisms that economic elites use to maintain their privileged position are summarized in these five propositions. The first indicates that investors' behavior is motivated by the desire to avoid playing risky games (which is not the same as the assumption of risk aversion). This motivation implies that the wealthy will be able to invest in projects marked by high returns and high risks, given their higher capacity to bear large losses compared to less wealthy investors (Figueroa, 2015, vol. 2, chap. 6). The second proposition is self-explanatory. The third is related to Michał Kalecki's theory (1971, chap. 12) and could be called Kaleckian threat. Because investors are free to select countries in which to invest, they are offered the best incentives by national governments, or else they would invest in other countries. The fourth proposition simply indicates that technological innovations are endogenous.

The fifth proposition introduces the significance of social networks in the persistence of elites. Elites are endowed not only with considerable physical capital but also with high social capital; they belong to the social networks of the wealthy. The social network operates as a social club of the wealthy, in which the exchange of favors is the binding social practice. This social network provides individual members with social protection against uninsurable risks, reducing greatly the risk of economic disasters, which equate to "leaving the club".

Individuals across all classes seek social protection through social networks, from poor peasant families to the capitalist class; moreover, they all aspire to membership of higher-level social networks. However, there is no market for social networks, nor for friends. Market exchange leads to social relations, but they are based on selfish motives, not on disinterested favors. Thus, economic elites have an advantage in their access to wealthy social networks, which is the result of non-market competition. It should be noted that all of above-mentioned advantages enjoyed by elites stem from their endowments of physical and social capital. These endowments block elite circulation, and precede competition in the market place.

According to this theory, elites cannot be dethroned endogenously in the economic process. In particular, they have the capacity to resist business risks and protect themselves against situations that could result in economic disaster for them (leaving the club). They are too wealthy to fail; the firms they own may fail, but they themselves will not. The elite also has the power to impose their will upon other interests, such as national 
governments and the media (Schutz, 2011, chap. 9). This economic and political power is exercised by elites to increase their wealth all the more.

As elite theory predicts, because of such advantages of scale, the competition mechanisms to dethrone members of the elite and thus generate a high degree of elite circulation is very weak; initial conditions are very important and thus there is a kind of path dependence in the evolution of elites.

This result is also consistent with the hypothesis put forward by sociologist T.B. Bottomore (1964), who stated: "The elite undergoes changes in its membership ordinarily by the recruitment of new individual members from the lower strata of society, sometimes by the incorporation of new social groups, and occasionally by the complete replacement of the established elite by a counter elite, as occurs in revolutions" (p. 12). Bottomore refers here to the concept of political elites, but the hypothesis would seem to be applicable to economic elites as well. Elite theory predicts that significant elite circulation is exogenous to the economic process. It will come from revolutions, political or technological.

In sum, the elite theory proposed here predicts low elite circulation in the economic process. Changes may occur, but they will be exogenously determined. This prediction is consistent with the findings set out in the previous section. Thus, the theory can be accepted at this stage of our research.

\section{MARKET COMPETITION VS META-COMPETITION}

The idea that free markets are conducive to strong competition is the most fundamental belief of current liberal thinking. However, markets are usually taken as the only places where capitalists compete.

As shown above, prior competition takes place among capitalists, whereby they compete with one other to become part of the economic elite and thus obtain the corresponding advantages. In this space, capitalists compete on the basis of their initial endowments. Those endowed with extensive capital enjoy an advantage over the others - the advantage of scale - through the mechanisms pointed out above. The very wealthy have a higher capacity to absorb losses when investing; they have greater access to capital markets, more benefits in negotiating investment projects with national governments, and the advantage of having the protection of a social network - namely, as we have seen, a club made up of the very wealthy. Elite competition is a kind of meta-competition, or "first-order" competition, which precedes market competition. Moreover, elite competition is an essential determinant of market competition, as we will now argue.

The fact that elite circulation is exogenously determined in the economic process implies that first-order competition is not the fundamental form of competition under modern capitalism. This explains the low degree of circulation in the world economic elite observed in the period 2002-2014, as shown above. However, elite competition 
seems to be the most important type of competition in attaining more efficient and egalitarian capitalism. This is the case because elites have a great influence on the allocation of investment to industries, countries, and types of technological innovations.

Is physical capital concentrated in the hands of the best possible elite, the most talented people for those tasks that constitute a good society? Is the current economic elite the result of Darwinian competition?

Social scientist Vilfredo Pareto discussed this problem, expressing great concern with this type of competition. As John Higley (2010) summarizes, "Pareto postulated that in a society with truly unrestricted social mobility, elites would consist of the most talented and deserving individuals" (p. 161). Thus, Pareto advocated a society with very high social mobility so that the circulation of the elite could be similarly high, which would guarantee competition among individual elites from which the best elite group would emerge. Expressed in terms of our theoretical framework, he was advocating a higher degree of meta-competition or "first-order" competition. However, in the current capitalist society, elite competition is very low, as shown above. No Darwinian evolutionary mechanism exists that naturally selects (endogenously) the best elite.

We will now consider some of the relationships between meta-competition and market competition, between first-order and second-order competition. On the one hand, market competition will not change the relative position of the economic elites. Elite circulation is not endogenous; it does not depend upon the outcome of prices and quantities in the market system. Elites are protected against economic disasters. It follows that the result of market competition will merely reproduce the initial wealth inequality. On the other hand, lack of competition at the meta-competition level will determine the degree of market competition. The low degree of elite circulation will mean highly concentrated ownership of capital; given this initial condition, markets will necessarily operate with oligopolistic market structures. Capital property structure and market structure are closely related. The conventional wisdom that perfect competition in the market place tends to prevail in the economic process is inconsistent with the existence and persistence of economic elites. A very competitive market system requires a high degree of elite circulation.

The oft-discussed problem of market efficiency in standard economics is therefore about second-order efficiency. This is a misplaced problem, for market efficiency depends upon efficiency in the meta-competition. Whether the concentration of wealth in the economic elite constitutes the most efficient allocation of physical and financial capital among individuals in society is therefore the pertinent question with which to start. The fact that the elite is reproduced in the market system does not imply that it is the best elite; under this criterion of market survival, any elite would always be the best. According to the elite theory, market survival corresponds to the scale effect of large wealth endowment; that is, the advantage of scale conceals the inefficiency that comes from the lack of strong meta-competition. 
What is striking is that Vilfredo Pareto is mostly known in standard economics for his concept of efficiency, known as Pareto optimality. However, this concept refers to second-order competition, that of market competition, given the wealth distribution and the composition of the elite. According to elite theory, it is to be expected that another elite, the result of first order competition, would imply a more efficient and better quality society. The initial distribution of endowments can only be changed through non-market competition.

The elite theory put forward here predicts a low degree of meta-competition; that is, that elites do not tend to circulate endogenously. The empirical fact, also presented here, supports this modern elite theory.

The new literature on economic elites is concerned with the formation of the transnational capitalist class amid globalization. The role of social networks in this formation is found to be very significant (Carroll, 2010). Globalization has not led to competing elites but to the rise of a strong transnational elite, the core of which is comprised of corporate elites from the core countries (USA and UK), and which form a powerful opponent for any competing faction in the global corporate elite; moreover, in 2013 , nearly 370 thousand businessmen - $11 \%$ of all directors of the top one million firms - were interlocking directors, holding positions in at least two firms (Heemskerk $\&$ Takes, 2016). These empirical results also support our conclusions. In particular, the findings of Heemskerk and Takes extend our conclusions based on the elite core of 80 individuals to a larger number, which in relative terms is still a small fraction.

\section{COMPARATIVE ADVANTAGE IN INTERNATIONAL TRADE}

The idea that countries, under a free market system, specialize in international trade according to their comparative advantage, is a persistent one in standard economics. This refers to static comparative advantages - that is, given resource endowments and technology. In dynamic terms, however, comparative advantage depends upon the allocation of investments and new technologies to countries' economic sectors.

Not only is wealth concentrated in the hands of the economic elite, but so too are the investment flows in the world economy. Their decisions on where to allocate their investments determine the dynamic comparative advantage of countries. The larger the concentration of elites in a given country, the more important direct foreign investment will become. One indicator of the economic power wielded by world elites through their transnational corporations can be discerned from the following: UNCTAD estimates that about $80 \%$ of global international trade is linked to the international production networks of transnational corporations (UNCTAD, 2013, Chapter IV). Therefore, economic elites stand as the world's planners as regards growth, employment, and income inequality within and between countries. 
In spite of the increasing globalization of the world economy, and the long-term economic growth experienced everywhere, the fact is that world income inequality is high and persistent (Milanovic, 2005). The main reason that income inequality within and between countries does not decrease as part of the process of economic growth is that inequality in wealth does not decline with economic growth - that is, inequality in wealth is indeed exogenous to the economic growth process (Figueroa, 2015, Volume II, Chapter 6). Theoretically and empirically, changes in the circulation of elites are not endogenous, but exogenous to the economic process. It is no paradox that overall income inequality has been persistent over time.

\section{CONCLUSIONS}

This paper has two main findings, one empirical and the other theoretical. Firstly, by analyzing a new and unique data set on the world economic elite for the period 2002-2014, it has developed an index to measure the degree of elite circulation, which is subsequently applied to the data set. The empirical finding is that the world economic elite exhibits a low degree of circulation. In spite of extensive globalization, liberalization, long-term economic growth, and the recent Great Economic Recession, the core of the world elite remains mostly unchanged. Secondly, the paper has offered a theoretical explanation for this fact, which concerns elite theory. The scale effect of large wealth ownership gives the elite the mechanism with which to preserve their status, marked by high economic and political power. Members of the economic elite are too wealthy to fail.

The observed fact of low elite circulation implies that competition to become part of the elite, the first order competition, is also weak. Thus, it follows that the existence of an elite hardcore leads to a market system that operates by way of oligopolistic market structures. This prediction of elite theory is consistent with what we observe in the real world with respect to market structures. To be sure, a high degree of market competition would require a high degree of elite circulation, which is not the case in the real world.

Furthermore, elites wield economic and political power, especially over national governments. Elites also have the power to influence the dynamic comparative advantage of nations, together with their growth rate and degree of income inequality. Income inequality, within and between countries, does not decrease as part of the process of economic growth because the concentration of physical and financial capital in the hands of the elites does not change endogenously. The degree of elite circulation can only change exogenously.

The high concentration of capital in the hands of the elite is important for the quality of society not only in terms of moral values regarding the unfairness of inequality. It is also important, as has been shown in this paper, because the elite play a significant role in shaping our society and its future. Economic elites are the world's planners, but without the consent of the people. 


\section{APPENDIX}

A1. Tables

Table A1.1 Country classification

\begin{tabular}{ccc}
\hline First World & Third World & Non-capitalist \\
\hline Australia & Brazil & China \\
Canada & Chile & Czech Republic \\
Cyprus & Colombia & Romania \\
France & Egypt & Russia \\
Germany & Hong Kong & Ukraine \\
Greece & India & \\
Italy & Kuwait & \\
Japan & Malaysia & \\
Netherlands & Mexico & \\
Spain & Nigeria & \\
Sweden & Philippines & \\
Switzerland & Saudi Arabia & \\
United Kingdom & South Africa & \\
United States & South Korea & \\
& Taiwan & \\
& Thailand & \\
& United Arab Emirates & \\
& Venezuela & \\
\hline
\end{tabular}

Note: Classificatión is based on income per capita levels in the period 1950-2010 and the dominant political regimes in that period.

Source: Figueroa (2015, volume 1, chapter 2). Own elaboration. 
Table A1.2 Frequency distribution and some calculations for the integral circulation index

\begin{tabular}{cccc}
\hline $\mathbf{t}$ & $\mathbf{n}$ & $\mathbf{t}^{2}$ & $\mathbf{t}^{2} \mathbf{n}$ \\
\hline 1 & 40 & 1 & 40 \\
2 & 25 & 4 & 100 \\
3 & 24 & 9 & 216 \\
4 & 16 & 16 & 256 \\
5 & 12 & 25 & 300 \\
6 & 12 & 36 & 432 \\
7 & 9 & 49 & 441 \\
8 & 3 & 64 & 192 \\
9 & 10 & 81 & 810 \\
10 & 7 & 100 & 700 \\
11 & 6 & 121 & 726 \\
12 & 8 & 144 & 1152 \\
13 & 21 & 169 & 3549 \\
\hline Totales & 193 & 819 & 8914 \\
\hline
\end{tabular}

Note: $\mathrm{T}=13, \mathrm{~N}=193$. Own elaboration.

\section{A2. The integral circulation index}

The integral circulation index measures the degree of circulation of the elite, taking into account the entire distribution of frequencies. It has three components:

$c:$ Basic circulation (empirical list in relation to the theoretical maximum);

$p_{1}$ : Penalty for mortality rate;

$p_{2}$ : Penalty for frequency distribution (repetition).

Then,

$$
C^{*}=c \cdot p_{1} \cdot p_{2}
$$

Where,

$$
\begin{gathered}
c=\frac{N}{E T} \\
p_{1}=1-\frac{m}{N} \\
p_{2}=\ln \left(e^{1-J}\right)
\end{gathered}
$$


In this notation, the symbol $E$ represents the size of the elite defined for the study, $T$ the number of years under observation, $N$ the total number of people who appear on the list in period $T, m$ the number of deaths among the elite during the period $T$. Thus, $J$ captures the frequency distribution function through a weighted average, where the weights are the square of the number of times that each name appears; hence, $J$ has a range $[0,1]$. When $J=0$, perfect circulation exists. That is, all names appear only once; thus $p_{2}=1$, which implies that no penalty is imposed on index $C^{*}$. On the other hand, when $J=1$, there is zero circulation, i.e. all names are concentrated in the maximum number of years, and their frequency is equal to $T$. In this case $p_{2}=0$, reflecting zero circulation and penalizing completely the index $C^{*}$.

Thus, $J$ is defined as follows:

$$
J=\frac{F-F_{\text {min }}}{F_{\text {max }}-F_{\text {min }}}, \quad J \in[0,1]
$$

Where:

$$
\begin{gathered}
F=\frac{\sum_{i=1}^{T} t_{i}^{2} n_{i}}{\sum_{i=1}^{T} t_{i}^{2}} \\
F_{\max }=\frac{T^{2} N}{\sum_{i=1}^{T} t_{i}^{2}} \\
F_{\min }=\frac{E}{\sum_{i=1}^{T} t_{i}^{2}}
\end{gathered}
$$

Here, $t$ is the number of times that the names are repeated, up to $T$, which is the total period under study, $t \in[1, T] ; n_{i}$ is the number of people listed in the ranking for a number $t_{i}$ of years, $n \in[E, N]$ and $N \in[E, E T]$.

The long version of index $C^{*}$, which clearly shows its three components, is given by:

$$
C^{*}=\frac{N}{E T}\left(1-\frac{m}{N}\right) \ln \left(e^{1-\frac{F-F_{\min }}{F_{\max }-F_{\min }}}\right)
$$

After simplifying, we obtain: 


$$
C^{*}=\frac{N-m}{E T} \ln \left(e^{\frac{F_{\max }-F}{F_{\max }-F_{\min }}}\right)
$$

In order to proceed with the empirical application, the frequency distribution and other necessary elements for the calculation of $C^{*}$ are shown in table A1.2.

Step 1.- Calculation of $c$ :

$$
c=\frac{193}{80 * 13}=0.186
$$

Step 2.- Calculation of $p_{1}$ :

(At present there is no available information regarding deaths among the elite. We assume that no member has died over the period, which is an optimistic assumption. Thus, no penalty for mortality is imposed).

$$
p_{1}=1-\frac{0}{193}=1
$$

Step 3.- Calculation of $p_{2}$ :

$$
\begin{gathered}
F=\frac{8914}{819}=10.884 \\
F_{\text {max }}=\frac{13^{2} * 193}{819}=39.825 \\
F_{\text {min }}=\frac{80}{819}=0.098 \\
J=\frac{10.884-0.098}{39.825-0.098}=0.272 \\
p_{2}=\ln \left(e^{1-0.272}\right)=0.728
\end{gathered}
$$

Step 4.- Calculation of the integral circulation index:

$$
C^{*}=c \cdot p_{1} \cdot p_{2}=0.186 * 1 * 0.728=0.135
$$


A3. The richest people in the world by year, 2002-2014

\begin{tabular}{|c|c|c|c|c|c|c|c|}
\hline & \multirow{2}{*}{ Name } & \multirow{2}{*}{$\mathbf{N}^{1 /}$} & \multicolumn{2}{|c|}{ Ranking $^{2 /}$} & \multicolumn{2}{|c|}{ Net worth $(\$ \mathrm{mil})^{3 /}$} & \multirow{2}{*}{ Country } \\
\hline & & & Median & Mean & Median & Mean & \\
\hline 1 & Bill Gates & 13 & 1.0 & 1.5 & 53,000 & 54,123 & USA \\
\hline 2 & Warren Buffett & 13 & 2.0 & 2.5 & 44,000 & 46,008 & USA \\
\hline 3 & Carlos Slim Helu \& family & 13 & 3.0 & 6.9 & 49,000 & 44,008 & MEX \\
\hline 4 & Larry Ellison & 13 & 6.0 & 8.0 & 23,500 & 27,438 & USA \\
\hline 5 & Amancio Ortega & 13 & 10.0 & 14.7 & 20,200 & 25,615 & ESP \\
\hline 6 & Bernard Arnault \& family & 13 & 13.0 & 15.1 & 25,500 & 23,415 & FRA \\
\hline 7 & Jim Walton & 13 & 14.0 & 14.5 & 20,000 & 20,946 & USA \\
\hline 8 & Liliane Bettencourt \& family & 13 & 15.0 & 14.2 & 20,000 & 20,800 & FRA \\
\hline 9 & Alice Walton & 13 & 16.0 & 15.9 & 20,000 & 20,738 & USA \\
\hline 10 & S. Robson Walton & 13 & 17.0 & 16.5 & 19,800 & 20,677 & USA \\
\hline 11 & Li Ka-shing & 13 & 14.0 & 15.5 & 21,000 & 20,169 & HKG \\
\hline 12 & Prince Alwaleed Bin Talal Alsaud & 13 & 19.0 & 16.8 & 20,000 & 19,608 & SAU \\
\hline 13 & Stefan Persson & 13 & 18.0 & 24.3 & 17,700 & 17,715 & SWE \\
\hline 14 & Paul Allen & 13 & 33.0 & 28.6 & 16,000 & 17,338 & USA \\
\hline 15 & Michael Dell & 13 & 30.0 & 31.3 & 15,300 & 14,485 & USA \\
\hline 16 & Steve Ballmer & 13 & 31.0 & 31.8 & 14,500 & 14,169 & USA \\
\hline 17 & Michael Otto \& family & 13 & 41.0 & 39.8 & 13,300 & 12,992 & DEU \\
\hline 18 & Anne Cox Chambers & 13 & 46.0 & 45.8 & 12,000 & 11,792 & USA \\
\hline 19 & Carl Icahn & 13 & 48.0 & 47.5 & 10,500 & 11,723 & USA \\
\hline 20 & Leonardo Del Vecchio & 13 & 53.0 & 55.9 & 10,000 & 10,223 & ITA \\
\hline 21 & Phil Knight & 13 & 56.0 & 57.7 & 9,500 & 10,054 & USA \\
\hline 22 & Lee Shau Kee & 12 & 33.0 & 36.1 & 17,500 & 14,350 & HKG \\
\hline 23 & Thomas \& Raymond Kwok \& family & 12 & 28.5 & 29.0 & 13,300 & 14,200 & HKG \\
\hline 24 & Forrest Mars Jr & 12 & 39.5 & 39.4 & 10,450 & 12,092 & USA \\
\hline 25 & Jacqueline Mars & 12 & 40.5 & 40.4 & 10,450 & 12,092 & USA \\
\hline 26 & John Mars & 12 & 41.5 & 41.4 & 10,450 & 12,092 & USA \\
\hline 27 & Abigail Johnson & 12 & 39.0 & 41.9 & 11,750 & 11,825 & USA \\
\hline & Mikhail Fridman & 12 & 48.5 & 51.9 & 12,650 & 11,800 & RUS \\
\hline 29 & Susanne Klatten & 12 & 53.0 & 51.9 & 10,550 & 11,075 & DEU \\
\hline 30 & Lakshmi Mittal & 11 & 6.0 & 19.3 & 23,500 & 24,064 & IND \\
\hline 31 & Karl Albrecht & 11 & 10.0 & 11.6 & 23,500 & 22,945 & DEU \\
\hline & Mukesh Ambani & 11 & 19.0 & 27.4 & 20,100 & 20,227 & IND \\
\hline 33 & George Soros & 11 & 37.0 & 40.8 & 11,000 & 12,455 & USA \\
\hline
\end{tabular}




\begin{tabular}{|c|c|c|c|c|c|c|c|}
\hline & \multirow{2}{*}{ Name } & \multirow{2}{*}{$\mathbf{N}^{1 /}$} & \multicolumn{2}{|c|}{ Ranking $^{2 /}$} & \multicolumn{2}{|c|}{ Net worth $(\$ \mathrm{mil})^{3 /}$} & \multirow{2}{*}{ Country } \\
\hline & & & Median & Mean & Median & Mean & \\
\hline 34 & Azim Premji & 11 & 41.0 & 41.6 & 13,300 & 12,400 & IND \\
\hline 35 & Birgit Rausing \& family & 11 & 49.0 & 42.0 & 11,000 & 11,364 & SWE* \\
\hline 36 & Charles Koch & 10 & 22.0 & 28.5 & 17,250 & 19,750 & USA \\
\hline 37 & Larry Page & 10 & 27.0 & 28.6 & 18,050 & 17,850 & USA \\
\hline 38 & Sergey Brin & 10 & 25.0 & 27.8 & 18,100 & 17,800 & USA \\
\hline 39 & Michele Ferrero \& family & 10 & 36.0 & 38.9 & 14,000 & 14,990 & ITA \\
\hline 40 & Roman Abramovich & 10 & 37.0 & 36.0 & 12,700 & 13,520 & RUS \\
\hline 41 & Francois Pinault \& family & 10 & 60.0 & 60.3 & 12,250 & 11,560 & FRA \\
\hline 42 & Nasser Al-Kharafi \& family & 10 & 49.0 & 51.8 & 8,850 & 9,330 & $\mathrm{KWT}^{*}$ \\
\hline 43 & Christy Walton \& family & 9 & 12.0 & 14.8 & 22,500 & 23,178 & USA \\
\hline 44 & Sheldon Adelson & 9 & 14.0 & 19.7 & 24,900 & 22,911 & USA \\
\hline 45 & Ingvar Kamprad \& family & 9 & 7.0 & 8.9 & 23,000 & 22,767 & SWE \\
\hline 46 & David Koch & 9 & 20.0 & 23.8 & 17,500 & 21,500 & USA \\
\hline 47 & Michael Bloomberg & 9 & 23.0 & 35.7 & 18,000 & 17,200 & USA \\
\hline 48 & Vladimir Lisin & 9 & 41.0 & 40.4 & 15,800 & 15,411 & RUS \\
\hline 49 & Vagit Alekperov & 9 & 56.0 & 54.9 & 13,000 & 12,289 & RUS \\
\hline 50 & Donald Bren & 9 & 69.0 & 62.2 & 12,000 & 11,211 & USA \\
\hline 51 & Gerald Cavendish Grosvenor \& family & 9 & 45.0 & 46.6 & 11,000 & 10,544 & GBR \\
\hline 52 & Ernesto Bertarelli \& family & 9 & 64.0 & 62.6 & 8,200 & 7,856 & $\mathrm{CHE}$ \\
\hline 53 & David Thomson \& family & 8 & 24.0 & 23.5 & 19,650 & 19,538 & CAN \\
\hline 54 & Silvio Berlusconi \& family & 8 & 42.0 & 46.3 & 9,500 & 9,175 & ITA \\
\hline 55 & Hans Rausing & 8 & 45.0 & 48.6 & 8,350 & 8,638 & SWE \\
\hline 56 & Theo Albrecht & 7 & 20.0 & 18.9 & 17,500 & 17,829 & USA* $^{*}$ \\
\hline 57 & Mikhail Prokhorov & 7 & 39.0 & 43.7 & 13,400 & 14,300 & RUS \\
\hline 58 & Iris Fontbona \& family & 7 & 55.0 & 51.9 & 15,500 & 13,843 & $\mathrm{CHL}$ \\
\hline 59 & Alexey Mordashov & 7 & 54.0 & 50.4 & 12,800 & 13,786 & RUS \\
\hline 60 & Viktor Vekselberg & 7 & 59.0 & 57.9 & 12,400 & 12,757 & RUS \\
\hline & Mohammed Al Amoudi & 7 & 63.0 & 63.3 & 12,300 & 11,357 & SAU \\
\hline 62 & John Kluge & 7 & 30.0 & 42.0 & 10,500 & 9,514 & $\mathrm{DEU}^{*}$ \\
\hline 63 & Serge Dassault $\&$ family & 7 & 62.0 & 62.0 & 8,500 & 9,229 & FRA \\
\hline 64 & Charles Ergen & 7 & 56.0 & 55.1 & 7,200 & 8,586 & USA \\
\hline & Jeff Bezos & 6 & 28.0 & 34.0 & 18,250 & 18,800 & USA \\
\hline & Helen Walton & 6 & 12.0 & 14.8 & 17,250 & 17,817 & USA* $^{*}$ \\
\hline 67 & Vladimir Potanin & 6 & 42.0 & 44.0 & 14,400 & 14,950 & RUS \\
\hline 68 & Joseph Safra & 6 & 61.0 & 60.0 & 12,600 & 12,350 & BRA \\
\hline
\end{tabular}




\begin{tabular}{|c|c|c|c|c|c|c|}
\hline \multirow{2}{*}{ Name } & \multirow{2}{*}{$\mathbf{N}^{1 /}$} & \multicolumn{2}{|c|}{ Ranking $^{2 /}$} & \multicolumn{2}{|c|}{ Net worth $(\$ \mathrm{mil})^{3 /}$} & \multirow{2}{*}{ Country } \\
\hline & & Median & Mean & Median & Mean & \\
\hline 69 Ronald Perelman & 6 & 68.0 & 64.0 & 12,000 & 11,867 & USA \\
\hline 70 Barbara Cox Anthony & 6 & 25.0 & 27.3 & 11,450 & 11,383 & USA* \\
\hline 71 Kirk Kerkorian & 6 & 43.0 & 46.5 & 8,800 & 10,067 & USA \\
\hline 72 Stefan Quandt & 6 & 68.0 & 68.2 & 8,700 & 9,050 & DEU \\
\hline 73 Rupert Murdoch \& family & 6 & 52.5 & 57.7 & 7,800 & 8,217 & USA \\
\hline 74 Gerard Wertheimer & 6 & 67.0 & 64.7 & 7,750 & 8,083 & FRA \\
\hline 75 Pierre Omidyar & 6 & 51.5 & 53.7 & 8,650 & 7,817 & USA \\
\hline 76 August von Finck & 6 & 67.5 & 65.2 & 6,500 & 6,200 & $\mathrm{DEU}$ \\
\hline 77 Kenneth Thomson \& family & 5 & 14.0 & 13.2 & 17,200 & 16,720 & CAN* $^{*}$ \\
\hline 78 Oleg Deripaska & 5 & 40.0 & 41.0 & 13,300 & 15,320 & RUS \\
\hline 79 Jorge Paulo Lemann & 5 & 49.0 & 48.2 & 13,300 & 14,860 & BRA \\
\hline 80 German Larrea Mota Velasco \& family & 5 & 48.0 & 53.2 & 14,700 & 14,260 & MEX \\
\hline 81 John Paulson & 5 & 63.0 & 61.8 & 12,500 & 12,000 & USA \\
\hline 82 Robert Kuok & 5 & 64.0 & 60.6 & 12,500 & 11,780 & MYS \\
\hline 83 Georg Schaeffler & 5 & 71.0 & 72.2 & 6,800 & 8,440 & DEU \\
\hline 84 Sumner Redstone & 5 & 35.0 & 39.8 & 8,100 & 8,300 & USA \\
\hline 85 Donald Newhouse & 5 & 58.0 & 51.8 & 7,500 & 6,980 & USA \\
\hline 86 Samuel Newhouse Jr & 5 & 59.0 & 52.8 & 7,500 & 6,980 & USA \\
\hline 87 Edward Johnson III & 5 & 74.0 & 74.0 & 6,000 & 6,280 & USA \\
\hline 88 Curt Engelhorn & 5 & 69.0 & 62.0 & 5,900 & 5,900 & DEU \\
\hline 89 Eike Batista & 4 & 8.0 & 21.0 & 28,500 & 23,625 & BRA \\
\hline 90 Anil Ambani & 4 & 26.0 & 23.5 & 15,950 & 21,000 & IND \\
\hline 91 John Walton & 4 & 9.5 & 9.5 & 19,100 & 18,850 & USA $^{*}$ \\
\hline 92 Mark Zuckerberg & 4 & 44.0 & 44.0 & 15,500 & 18,200 & USA \\
\hline 93 Alisher Usmanov & 4 & 34.5 & 34.5 & 17,900 & 18,000 & RUS \\
\hline 94 Theo Albrecht Jr \& family & 4 & 34.5 & 37.0 & 18,350 & 17,600 & DEU \\
\hline 95 Aliko Dangote & 4 & 47.0 & 48.8 & 14,950 & 16,525 & NGA \\
\hline 96 Len Blavatnik & 4 & 58.0 & 58.8 & 13,950 & 14,175 & USA \\
\hline 97 Luis Carlos Sarmiento & 4 & 68.5 & 69.3 & 13,150 & 12,750 & $\mathrm{COL}$ \\
\hline 98 Spiro Latsis \& family & 4 & 55.0 & 57.8 & 10,050 & 9,650 & GRC \\
\hline 99 Adolf Merckle & 4 & 54.5 & 55.8 & 9,200 & 9,125 & $\mathrm{DEU}^{*}$ \\
\hline 100 Galen Weston \& family & 4 & 44.5 & 46.3 & 8,050 & 8,050 & CAN \\
\hline 101 Rudolf August Oetker \& family & 4 & 53.5 & 54.5 & 7,600 & 7,175 & DEU* \\
\hline 102 Nobutada Saji & 4 & 46.5 & 50.5 & 7,000 & 7,100 & JPN \\
\hline 103 Friedrich Flick Jr & 4 & 61.0 & 61.3 & 5,750 & 5,750 & DEU* \\
\hline
\end{tabular}




\begin{tabular}{|c|c|c|c|c|c|c|}
\hline \multirow{2}{*}{ Name } & \multirow{2}{*}{$\mathbf{N}^{1 /}$} & \multicolumn{2}{|c|}{ Ranking $^{2 /}$} & \multicolumn{2}{|c|}{ Net worth $(\$ \mathrm{mil})^{3 /}$} & \multirow{2}{*}{ Country } \\
\hline & & Median & Mean & Median & Mean & \\
\hline 104 Philip Anschutz & 4 & 69.5 & 68.3 & 5,150 & 5,250 & USA \\
\hline 105 Gina Rinehart & 3 & 39.0 & 38.0 & 17,700 & 17,567 & AUS \\
\hline 106 Kushal Pal Singh & 3 & 66.0 & 49.3 & 10,000 & 16,333 & IND \\
\hline 107 Cheng Yu-tung & 3 & 45.0 & 46.3 & 16,000 & 16,067 & HKG \\
\hline 108 Rinat Akhmetov & 3 & 40.0 & 42.0 & 16,000 & 15,800 & UKR \\
\hline 109 Alberto Bailleres Gonzalez \& family & 3 & 38.0 & 45.3 & 16,500 & 15,533 & MEX \\
\hline 110 Shashi \& Ravi Ruia & 3 & 42.0 & 42.3 & 15,000 & 14,600 & IND \\
\hline 111 Leonid Mikhelson & 3 & 57.0 & 59.3 & 15,400 & 14,300 & RUS \\
\hline 112 Suleiman Kerimov & 3 & 36.0 & 48.0 & 14,400 & 13,000 & RUS \\
\hline 113 Jack Taylor \& family & 3 & 42.0 & 44.0 & 13,900 & 12,467 & USA \\
\hline 114 Tadashi Yanai \& family & 3 & 66.0 & 63.7 & 13,300 & 12,400 & JPN \\
\hline 115 Savitri Jindal \& family & 3 & 56.0 & 60.0 & 12,200 & 12,100 & IND \\
\hline 116 John Fredriksen & 3 & 75.0 & 75.0 & 11,300 & 11,867 & CYP \\
\hline 117 Antonio Ermirio de Moraes & 3 & 74.0 & 73.0 & 12,200 & 11,633 & BRA \\
\hline 118 Viktor Rashnikov & 3 & 71.0 & 71.7 & 10,400 & 10,467 & RUS \\
\hline 119 George Kaiser & 3 & 68.0 & 62.0 & 10,000 & 10,000 & USA \\
\hline 120 Sunil Mittal \& family & 3 & 64.0 & 64.3 & 9,500 & 9,667 & IND \\
\hline 121 Reinhold Wuerth & 3 & 68.0 & 67.3 & 7,500 & 7,900 & $\mathrm{DEU}$ \\
\hline 122 Sulaiman Al Rajhi \& family & 3 & 74.0 & 64.0 & 6,200 & 7,600 & SAU \\
\hline 123 Robert Pritzker & 3 & 48.0 & 46.7 & 7,600 & 6,733 & USA $^{*}$ \\
\hline 124 Thomas Pritzker & 3 & 49.0 & 47.7 & 7,600 & 6,733 & USA \\
\hline 125 Luciano Benetton & 3 & 62.0 & 54.0 & 4,900 & 6,467 & ITA \\
\hline 126 Samuel Johnson & 3 & 52.0 & 52.7 & 7,300 & 6,400 & USA $^{*}$ \\
\hline 127 Eli Broad & 3 & 70.0 & 64.0 & 5,800 & 5,700 & USA \\
\hline 128 Yasuo Takei \& family & 3 & 61.0 & 59.0 & 5,200 & 5,467 & $\mathrm{JPN}^{*}$ \\
\hline 129 Albrecht & 2 & 3.0 & 3.0 & 26,200 & 26,200 & $\mathrm{DEU}^{*}$ \\
\hline 130 Dieter Schwarz & 2 & 29.0 & 29.0 & 20,300 & 20,300 & $\mathrm{DEU}$ \\
\hline 131 Gennady Timchenko & 2 & 63.0 & 63.0 & 14,700 & 14,700 & RUS \\
\hline 132 Ricardo Salinas Pliego \& family & 2 & 50.0 & 50.0 & 13,750 & 13,750 & MEX \\
\hline 133 Ray Dalio & 2 & 73.0 & 73.0 & 13,450 & 13,450 & USA \\
\hline 134 Harold Hamm & 2 & 73.5 & 73.5 & 12,800 & 12,800 & USA \\
\hline 135 Johanna Quandt & 2 & 45.5 & 45.5 & 11,850 & 11,850 & $\mathrm{DEU}$ \\
\hline 136 Mikhail Khodorkovsky & 2 & 21.0 & 21.0 & 11,500 & 11,500 & RUS* \\
\hline 137 Naguib Sawiris & 2 & 63.0 & 63.0 & 11,350 & 11,350 & EGY \\
\hline 138 Dmitry Rybolovlev & 2 & 69.0 & 69.0 & 10,700 & 10,700 & RUS \\
\hline
\end{tabular}




\begin{tabular}{|c|c|c|c|c|c|c|}
\hline \multirow{2}{*}{ Name } & \multirow{2}{*}{$\mathbf{N}^{1 /}$} & \multicolumn{2}{|c|}{ Ranking $^{2 /}$} & \multicolumn{2}{|c|}{ Net worth $(\$ \mathrm{mil})^{3 /}$} & \multirow{2}{*}{ Country } \\
\hline & & Median & Mean & Median & Mean & \\
\hline 139 Iskander Makhmudov & 2 & 71.5 & 71.5 & 10,200 & 10,200 & RUS \\
\hline 140 James Simons & 2 & 65.0 & 65.0 & 9,300 & 9,300 & USA \\
\hline 141 Abdul Aziz Al Ghurair \& family & 2 & 67.5 & 67.5 & 7,350 & 7,350 & $\mathrm{ARE}^{*}$ \\
\hline 142 Philip \& Cristina Green & 2 & 71.0 & 71.0 & 6,650 & 6,650 & GBR \\
\hline 143 Micky Arison & 2 & 67.5 & 67.5 & 6,200 & 6,200 & USA \\
\hline 144 Ty Warner & 2 & 55.5 & 55.5 & 6,000 & 6,000 & USA \\
\hline 145 Gordon Moore & 2 & 59.0 & 59.0 & 5,800 & 5,800 & USA \\
\hline 146 James Goodnight & 2 & 69.5 & 69.5 & 5,450 & 5,450 & USA \\
\hline 147 Fukuzo Iwasaki & 2 & 72.5 & 72.5 & 4,900 & 4,900 & $\mathrm{JPN}^{*}$ \\
\hline 148 Hasso Plattner & 2 & 76.0 & 76.0 & 4,900 & 4,900 & $\mathrm{DEU}$ \\
\hline 149 Pierre Landolt family & 2 & 62.0 & 62.0 & 4,900 & 4,900 & $\mathrm{CHE}^{*}$ \\
\hline 150 Gustavo Cisneros \& family & 2 & 67.0 & 67.0 & 4,500 & 4,500 & VEN \\
\hline 151 Marvin Davis & 2 & 69.5 & 69.5 & 4,500 & 4,500 & USA $^{*}$ \\
\hline 152 Lorenzo Mendoza \& family & 2 & 71.5 & 71.5 & 4,350 & 4,350 & VEN \\
\hline 153 Reinhard Mohn \& family & 2 & 77.5 & 77.5 & 4,200 & 4,200 & $\mathrm{DEU}^{*}$ \\
\hline 154 Lui Che Woo & 1 & 28.0 & 28.0 & 22,000 & 22,000 & HKG \\
\hline 155 Masayoshi Son & 1 & 44.0 & 44.0 & 18,400 & 18,400 & JPN \\
\hline 156 Wang Jianlin & 1 & 64.0 & 64.0 & 15,100 & 15,100 & $\mathrm{CHN}$ \\
\hline 157 Andrey Melnichenko & 1 & 57.0 & 57.0 & 14,400 & 14,400 & RUS \\
\hline 158 Dhanin Chearavanont \& family & 1 & 59.0 & 59.0 & 14,300 & 14,300 & THA \\
\hline 159 Laurene Powell Jobs \& family & 1 & 73.0 & 73.0 & 14,000 & 14,000 & USA \\
\hline 160 German Khan & 1 & 54.0 & 54.0 & 13,900 & 13,900 & RUS \\
\hline $161 \mathrm{Ma}$ Huateng & 1 & 80.0 & 80.0 & 13,400 & 13,400 & $\mathrm{CHN}$ \\
\hline 162 Henry Sy \& family & 1 & 68.0 & 68.0 & 13,200 & 13,200 & PHL \\
\hline 163 Lee Kun-Hee & 1 & 70.0 & 70.0 & 13,000 & 13,000 & KOR \\
\hline 164 Miuccia Prada & 1 & 78.0 & 78.0 & 12,400 & 12,400 & ITA \\
\hline 165 Alexander Abramov & 1 & 65.0 & 65.0 & 11,500 & 11,500 & RUS \\
\hline 166 Nassef Sawiris & 1 & 71.0 & 71.0 & 11,000 & 11,000 & EGY \\
\hline 167 Alexei Kuzmichev & 1 & 72.0 & 72.0 & 10,800 & 10,800 & RUS \\
\hline 168 Horst Paulmann \& family & 1 & 75.0 & 75.0 & 10,500 & 10,500 & $\mathrm{CHL}$ \\
\hline 169 Eliodoro Matte & 1 & 77.0 & 77.0 & 10,400 & 10,400 & $\mathrm{CHL}$ \\
\hline 170 Sammy Ofer \& family & 1 & 79.0 & 79.0 & 10,300 & 10,300 & ROU* \\
\hline 171 Kumar Birla & 1 & 76.0 & 76.0 & 10,200 & 10,200 & IND \\
\hline 172 Vladimir Yevtushenkov & 1 & 72.0 & 72.0 & 9,100 & 9,100 & RUS \\
\hline 173 Dan Duncan & 1 & 76.0 & 76.0 & 9,000 & 9,000 & USA $^{*}$ \\
\hline
\end{tabular}




\begin{tabular}{|c|c|c|c|c|c|c|}
\hline \multirow{2}{*}{ Name } & \multirow{2}{*}{$\mathbf{N}^{1 /}$} & \multicolumn{2}{|c|}{ Ranking $^{2 /}$} & \multicolumn{2}{|c|}{ Net worth $(\$ \mathrm{mil})^{3 /}$} & \multirow{2}{*}{ Country } \\
\hline & & Median & Mean & Median & Mean & \\
\hline 174 Rafael del Pino family & 1 & 79.0 & 79.0 & 8,600 & 8,600 & $\mathrm{ESP}^{*}$ \\
\hline 175 Suliman Olayan \& family & 1 & 34.0 & 34.0 & 7,600 & 7,600 & SAU* \\
\hline 176 Joseph \&\#38; Moise Safra & 1 & 69.0 & 69.0 & 7,400 & 7,400 & BRA* $^{*}$ \\
\hline 177 Ananda Krishnan & 1 & 65.0 & 65.0 & 7,000 & 7,000 & MYS \\
\hline 178 Maan Al-Sanea & 1 & 63.0 & 63.0 & 7,000 & 7,000 & SAU* \\
\hline 179 Mohamed Bin Issa Al Jaber & 1 & 62.0 & 62.0 & 7,000 & 7,000 & SAU \\
\hline $\begin{array}{l}180 \text { Khaled, Hayat, Hutham, Lubna } \\
\text { \&\#38; Olayan }\end{array}$ & 1 & 39.0 & 39.0 & 6,900 & 6,900 & SAU* \\
\hline 181 Nicky Oppenheimer \& family & 1 & 75.0 & 75.0 & 6,000 & 6,000 & ZAF \\
\hline 182 Petr Kellner & 1 & 77.0 & 77.0 & 6,000 & 6,000 & CZE \\
\hline 183 John Abele & 1 & 76.0 & 76.0 & 5,400 & 5,400 & USA $^{*}$ \\
\hline 184 Walter Haefner & 1 & 56.0 & 56.0 & 5,000 & 5,000 & $\mathrm{CHE}^{*}$ \\
\hline 185 Alfred Lerner & 1 & 67.0 & 67.0 & 4,700 & 4,700 & USA $^{*}$ \\
\hline 186 Tsai Wan Lin \& family & 1 & 69.0 & 69.0 & 4,600 & 4,600 & TWN* \\
\hline 187 Madeleine Schickedanz & 1 & 71.0 & 71.0 & 4,500 & 4,500 & $\mathrm{DEU}^{*}$ \\
\hline 188 Charlene de Carvalho-Heineken & 1 & 76.0 & 76.0 & 4,300 & 4,300 & NLD \\
\hline 189 David Sainsbury & 1 & 80.0 & 80.0 & 4,300 & 4,300 & GBR \\
\hline 190 Rolf Gerling & 1 & 77.0 & 77.0 & 4,300 & 4,300 & DEU \\
\hline 191 Akira Mori \& family & 1 & 77.0 & 77.0 & 4,100 & 4,100 & JPN \\
\hline 192 Eitaro Itoyama & 1 & 72.0 & 72.0 & 4,100 & 4,100 & $\mathrm{JPN}^{*}$ \\
\hline 193 Karl-Heinz Kipp & 1 & 75.0 & 75.0 & 4,100 & 4,100 & $\mathrm{DEU}$ \\
\hline
\end{tabular}

* Country not specified in the Oxfam data set.

${ }^{1 /}$ Number of years that he or she appears among the 80 richest people in 2002-2014.

${ }^{2 /}$ Ranking placement among the 80 richest people in 2002-2014.

${ }^{3 /}$ Anual mean of net worth in 2002-2014.

Source: Oxfam (2015). Own elaboration. 


\section{REFERENCES}

Bodley, J. (1999). Socio-economic growth, culture, scale, and household wellbeing: A test of the power-elite hypothesis. Current Anthropology, 40(5), 595-620. http://dx.doi. org/10.1086/300084

Bottomore, T. (1964). Elites and Society. New York: Penguin Books.

Carroll, W. (2010). The Making of a Transnational Capitalist Class: Corporate Power in the Twentyfirst Century. London: Zed Books.

Davies, J., S. Sandström, A. Shorrocks \& E. N. Wolff (2010). The level and distribution of global household wealth, Economic Journal, 121, 223-254. http://dx.doi.org/10.1111/j.14680297.2010.02391.x

Figueroa, A. (2008). Competition and circulation of economic elites: Theory and application to the case of Peru. The Quarterly Review of Economics and Finance, 48, 263-273. http:// dx.doi.org/10.1016/j.qref.2006.12.016

Figueroa, A. (2015). Growth, Employment, Inequality, and the Environment: Unity of Knowledge in Economics. Volumes I-II. New York: Palgrave Macmillan.

Heemskerk, E. \& F. Takes (2016). The corporate elite community structure of global capitalism. New Political Economy, 21(1), 90-118. http://dx.doi.org/10.1080/13563467.2015.1041 483

Higley, J. (2010). Elite Theory and Elites. In K.T. Leicht \& J.C. Jenkins (editors), Handbook of Politics: State and Society in Global Perspective. New York: Springer. http://dx.doi. org/10.1007/978-0-387-68930-2_9

Kalecki, M. (1971). Selected Essays in the Dynamics of Capitalist Society 1933-1970. Cambridge, UK: Cambridge University Press.

Milanovic, B. (2005). Worlds Apart: Measuring International and Global Inequality. Princeton, NJ: Princeton University Press. http://dx.doi.org/10.1515/9781400840816

OXFAM (2015). Wealth: Having it all and wanting more. Oxford, UK: Oxfam.

Piketty, T. (2014). Capital in the twenty-first century. Cambridge, MA: The Belknap Press of Harvard University Press. http://dx.doi.org/10.4159/9780674369542

Schutz, E. (2011). Inequality and Power. The Economics of Class. New York: Routledge. http:// dx.doi.org/10.4324/9780203828878

UNCTAD (United Nations Conference on Trade and Development) (2013). World Investment Report 2013. Geneva, Switzerland. http://dx.doi.org/10.18356/a3836fcc-en

Wolff, E. (1998). Recent trends in the size distribution of household wealth, Journal of Economic Perspectives, 12(3), 131-150. http://dx.doi.org/10.1257/jep.12.3.131

World Bank (2014). World Development Report 2014. Risk and opportunity. Managing risk for development. Washington, DC: The World Bank. http://dx.doi.org/10.1596/978-08213-9903-3

Documento recibido el 1 marzo de 2016 y aprobado el 15 de abril de 2016 